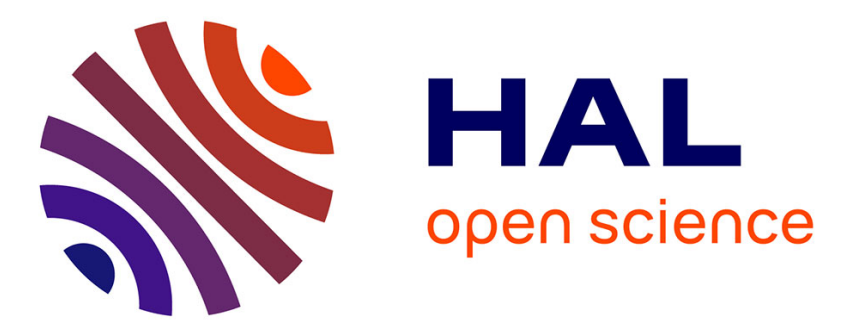

\title{
Biogeochemical processes in a clay formation in situ experiment: Part G - Key interpretations and conclusions. Implications for repository safety
}

Paul Wersin, S. Stroes-Gascoyne, F.J. Pearson, Christophe Tournassat, O.X. Leupin, B. Schwyn

\section{To cite this version:}

Paul Wersin, S. Stroes-Gascoyne, F.J. Pearson, Christophe Tournassat, O.X. Leupin, et al.. Biogeochemical processes in a clay formation in situ experiment: Part G - Key interpretations and conclusions. Implications for repository safety. Applied Geochemistry, 2011, 26, pp.1023-1034. 10.1016/j.apgeochem.2011.03.010 . hal-00597107

\section{HAL Id: hal-00597107 https: / hal-brgm.archives-ouvertes.fr/hal-00597107}

Submitted on 31 May 2011

HAL is a multi-disciplinary open access archive for the deposit and dissemination of scientific research documents, whether they are published or not. The documents may come from teaching and research institutions in France or abroad, or from public or private research centers.
L'archive ouverte pluridisciplinaire HAL, est destinée au dépôt et à la diffusion de documents scientifiques de niveau recherche, publiés ou non, émanant des établissements d'enseignement et de recherche français ou étrangers, des laboratoires publics ou privés. 
Biogeochemical Processes in a Clay Formation In-situ Experiment:

Part G - Key interpretations \& conclusions. Implications for repository safety

P. Wersin ${ }^{1,5^{*}}$, S. Stroes-Gascoyne, ${ }^{, 2}$, F.J. Pearson ${ }^{3}$, C. Tournassat ${ }^{4}$, O.X. Leupin ${ }^{1}$, B. Schwyn $^{1}$

${ }^{1}$ NAGRA, Hardstrasse 73, 5430 Wettingen, Switzerland

${ }^{2}$ Atomic Energy of Canada Limited (AECL), Whiteshell Laboratories, Pinawa, Manitoba

Canada, R0E 1L0

${ }^{3}$ Ground-Water Geochemistry, 5108 Trent Woods Drive, New Bern, NC 28562, USA

${ }^{4}$ BRGM, French Geological Survey, 3 avenue Claude Guillemin, B.P. 36009, 45060 Orléans

Cedex 2, France

${ }^{5}$ Gruner Ltd, Gellertstrasse 55, 4020 Basel, Switzerland

\footnotetext{
${ }^{*}$ Gruner Ltd

Gellertstrasse 55

CH-4020 Basel, Switzerland

E-mail: paul.wersin@gruner.ch

Tel: +416131764 15

Fax: +41612717948
} 


\begin{abstract}
The in-situ Porewater Chemistry (PC) experiment carried out in the Opalinus Clay formation at the Mont Terri Rock Laboratory, Switzerland for a period of five years allowed the identification and quantification of the biogeochemical processes resulting from and affected by an anaerobic microbial disturbance. The unintentional release of degradable organic compounds (mainly glycerol) induced microbially-mediated sulphate reduction in the borehole with concomitant significant geochemical changes in the circulating water and the adjacent porewater. These changes included a decrease in sulphate concentration and $\mathrm{pH}$ and an increase in $\mathrm{pCO}_{2}$ and alkalinity relative to the non-affected formation water. However, the cation composition of the water and the mineralogy of the clay close to the borehole wall showed very little change. This is explained by (1) the strong chemical buffering processes in the clay, such as cation and proton exchange reactions at the clay surfaces and carbonate dissolution/precipitation reactions and (2) by the diffusion-limited flux of solutes.
\end{abstract}

With the aid of a reactive transport model with a minimum set of kinetic parameters for the hypothesized degradation reactions, the evolution of solutes in the borehole could be modelled adequately. The model was also applied to the prediction of restoration times upon depletion of the carbon source and results indicated restoration times to undisturbed conditions of about 15 years, but also highlighted the rather large uncertainties inherent in the geochemical model. Nevertheless, the simulations provided additional evidence of the high pH buffer capacity of the Opalinus Clay.

The results from the microbiological investigations do not allow unambiguous identification of the origin of the microbial population in the borehole. Possible sources were the drilling procedure, the artificial porewater, and perhaps some revival of indigenous dormant strains. Regardless of the origin of the microbes, the results from the PC experiment underlined the importance of anaerobic microbial activity in the "disturbed" Opalinus Clay, 
facilitated by the introduction of space, water and organic material, in rapidly establishing very reducing conditions

The PC experiment also yielded valuable insight with regard to the safety of a high level radioactive waste repository emplaced in Opalinus Clay. Anaerobic microbial perturbations in the clay host rock may occur from the construction and excavation procedures and emplaced organic by-products. The resulting effects on porewater chemistry, i.e., especially on $\mathrm{pH}$ and Eh, may affect the mobility of radionuclides eventually released from the waste. However, the overall results of the PC experiment suggest that such effects are temporary and spatially limited because of the large buffering capacity and diffusive properties of the clay formation. Nevertheless, the results also indicate that the amounts of organic materials in a high-level waste repository should be kept small in order to achieve background conditions within a short time period after repository closure.

A further conclusion from the PC experiment is that commonly used equipment materials may not display commonly assumed inert behaviour. This particularly holds for the gel-type "robust" reference electrodes, which may release substantial amounts of glycerol.

Key words: clay formation, microbial disturbance, degradation, organics, modelling, safety case 
Argillaceous formations are foreseen as host rocks for nuclear waste repositories in an increasing number of countries, such as France, Belgium, Canada and Switzerland. Suitable indurated clay formations, such as for example the Opalinus Clay in Switzerland, display favourable hydraulic and mechanical properties, which include low permeability and the capacity of self-sealing (Nagra, 2002). Moreover, such formations are characterized by their remarkable geochemical stability (Beaucaire et al., 2004). This point is addressed in more detail below. The transport of radionuclides, which may eventually enter the geosphere once the canister containment is breached and the waste form is dissolving, is limited by diffusion and retardation processes (e.g. Nagra, 2002; Andra, 2005). These processes are affected by the porewater chemistry and, therefore, it is important to know the solute composition and the underlying processes which regulate it.

An in-situ experiment, termed the Porewater Chemistry (PC) experiment, designed to obtain better knowledge of porewater composition in the Opalinus Clay, was carried out in the Mont Terri Rock Laboratory for a period of five years. As described in a companion paper (Wersin et al., 2010; this issue) in this issue, the scope of this experiment was reformulated after observing unexpected microbiological activity in the packed-off borehole: it was recognized that it was important to understand the biogeochemical processes occurring in a "disturbed" clay formation and to interpret these also from a repository safety point of view, i.e. evaluate the possible consequences on the safety case (discussed later in this paper). Hence, an extensive experimental and modelling program was conducted during and after the in-situ PC test. The procedures and results of this work are presented in companion papers in this special issue: In Wersin et al. (2010; this issue), the experimental procedures for the insitu test are outlined and the results from the evolving water composition in the borehole are presented and interpreted qualitatively. Koroleva et al. (2010; this issue) gives the procedures 
of the overcoring and presents analytical results of the rock samples close to the borehole/rock interface. The experimental study related to the identification of the source(s) of degrading organic carbon is presented in De Cannière et al. (2010; this issue). The microbiological results from a variety of analyses are outlined and interpreted in Stroes-Gascoyne et al., (2010; this issue). Equilibrium constraints on porewater chemistry are discussed in Pearson et al. (2010; this issue). The quantitative interpretation of the biogeochemical processes, using reactive transport modelling, is given in Tournassat et al. (2010; this issue).

The objectives of this contribution are two-fold: First, the results from the PC experiment are summarized and the main conclusions formulated. Second, the results are discussed in the light of their relevance for the long-term safety of a repository embedded in a clay host rock. The main question in the latter is: How relevant is the observed microbial perturbation for the safety functions of the safety barriers, i.e., the host rock and the engineered components (e.g. the waste canisters)?

\section{Summary of procedures, analyses and modelling efforts}

As noted, the detailed procedures of the in-situ PC test and the accompanying laboratory and modelling work are presented in the different companion papers in this issue. Here only a brief summary is presented:

$\underline{\text { In-situ test: }}$

The in-situ PC experiment, which was carried out at the Mont Terri Rock Laboratory in the Liassic Opalinus Clay formation (Fig. 1), was based on the concept of diffusive equilibration: Traced synthetic water with a composition similar to that expected in the surrounding formation porewater was circulated in a packed-off vertical borehole (BPC-1). The contact between the synthetic water and the clay formation occurred via a $4.5 \mathrm{~m}$ polyethylene (PE) porous filter (previously washed with acetone to remove traces of grease). 
All materials in contact with the circulation water were made of chemically "inert" plastic materials (PE, polyamide, PEEK, polyurethane). The solution was monitored continuously online for pressure, temperature, $\mathrm{pH}$, Eh and EC. The $\mathrm{pH}$ and Eh electrodes contained gelfilled (polymer) reference electrodes and the initial EC electrode was of a graphite type. The $\mathrm{pH}$ electrode displayed non-linear drift and needed to be replaced at irregular intervals because of leakage of potassium and glycerol from the gel, as well as from the reaction of silver in the electrode with sulphide in the water. The graphite-type EC electrode was replaced by a more reliable platinum-type electrode because it showed anomalous behaviour. The Eh electrode displayed only small drift and was replaced only once within the five years of experimental duration.

\section{Analyses:}

The water was sampled at regular time intervals using Teflon-coated cylinders placed in the circuit. The analytical program included major chemistry components $(\mathrm{Na}, \mathrm{Ca}, \mathrm{Mg}, \mathrm{K}$, $\mathrm{Sr}, \mathrm{Cl}, \mathrm{SO}_{4}, \mathrm{HCO}_{3}$ ) and added tracers ( $\mathrm{HDO}, \mathrm{Br},{ }^{13} \mathrm{C}$-DIC), but was extended significantly after the discovery of microbial processes (after 6 months). Thus, various organic (TOC/DOC and its components: carboyxlic and other organic acids, alkanes) and inorganic species (Fe, $\mathrm{Mn}, \mathrm{NH}_{4}, \mathrm{Si}, \mathrm{Al}$, sulphur species) and isotopic ratios $\left({ }^{13} \mathrm{C}\right.$-DOC, ${ }^{14} \mathrm{C}-\mathrm{DIC},{ }^{14} \mathrm{C}-\mathrm{DOC},{ }^{18} \mathrm{O}-\mathrm{H}_{2} \mathrm{O}$, ${ }^{34} \mathrm{~S}_{-} \mathrm{SO}_{4},{ }^{34} \mathrm{~S}-\mathrm{H}_{2} \mathrm{~S}$ ) were also analyzed, in the later course of the experiment. Microbiological analysis of the PC borehole water started once it was apparent that there was a significant disturbance of the geochemistry from microbial activity. The PC water was analyzed for microbial characteristics in 2003, 2004, 2005 (twice) and 2006. At the termination of the PC experiment, both water and clay overcore samples were shipped by courier to three independent laboratories for much more extensive microbial analysis, which included both traditional culture-based and modern molecular methods. 
The circulation system was protected with a cabinet filled with argon to ensure anoxic conditions in the borehole. These conditions were disturbed during short intervals of electrode replacement and also by a few experimental difficulties during the five year period. The associated increase in Eh was quickly re-established to reducing conditions (within 1-2 days), as recorded from Eh measurements.

After a period of five years, the experiment was dismantled and the test interval section was overcored with a core diameter of $284 \mathrm{~mm}$. The focus of this overcoring exercise was to obtain mineralogical, geochemical and microbiological data of the rock, possibly disturbed by the biochemical processes in the borehole, and also of the potentially affected equipment material. Thus, rock samples were taken as a function of distance to the borehole and analyzed for standard parameters (water content, density), mineralogical composition (XRD, SEM-EDX), cation exchange properties, aqueous leachates and stable isotopes.

\section{Laboratory and modelling studies:}

$\mathrm{CO}_{2}$ gas measurements on two core samples from BPC-1 were carried out by gas extraction under controlled atmosphere after an equilibration period of 40 days. Furthermore, the isotopic compositions $\left(\delta^{13} \mathrm{C}, \delta^{18} \mathrm{O}\right.$ ) of the extracted $\mathrm{CO}_{2}$ as well of $\mathrm{CO}_{2}$ extracted from carbonate minerals (calcite, siderite, dolomite) were measured.

Undisturbed formation porewater was extracted from a core sample taken from a neighbouring borehole (BPC-A1). The extraction was performed by advective displacement in a pressure vessel where a high confining He pressure is applied (Mäder et al., 2004). Extracted water samples were analyzed for major constituents and $\mathrm{pH}$. Only the $\mathrm{pH}$ data are reported in this special issue (Wersin et al., 2010; this issue).

The leaching behaviour of samples from plastic equipment materials (PE, polyurethane, polyamide) was investigated to shed light on the carbon source fuelling the observed microbial activity in the borehole. In addition, soaking tests with PE immersed with 
acetone, under conditions similar to those used to wash the porous PE filter prior to installation, were carried out. A further potential carbon source is the polymer filling of the pH and Eh electrodes, which contains hydrophilic compounds (glycerol, polyethylene glycol and polyacrylate derivatives). Leaching tests with this gel-material were also conducted and the leachates analyzed.

The microbiological study of the PC experiment was necessarily limited to PC borehole water samples while the experiment was ongoing. Analyses during the period 20032006 were limited mainly to determining the total and active number of cells in the PC water (using a number of dyes and specific probes). At the termination of the PC experiment, carefully taken PC water- and clay overcore samples were shipped by courier to three independent laboratories for much more extensive microbial analyses, including: total and active cell counts, quantitative and enrichment culturing for a number of physiological groups, while molecular methods included phospholipid fatty acid (PLFA) analysis, quantitative polymerase chain reaction (QPCR); and DNA extraction followed by amplification, separation, sequencing and identification.

The modelling effort focused on the development of a "minimum" model that could reproduce the chemical evolution of the water composition (in the borehole and in the formation) during the experiment. The following items were necessary pre-requisites for the construction of this "minimum" model:

(i) Knowledge of the transport properties of the rock. These properties (i.e., diffusion coefficients and porosity) could be obtained from the tracer (HDO, Br) concentrations in the borehole water as a function of the time. Through the overcoring the analyses could be refined by taking into account the tracers' profiles in the rock and by providing direct measurements of the total and anion accessible porosities values, through water content analysis and anions leaching experiments. The transport properties are of premium importance because the flux of dissolved species from the 
borehole water to the formation and vice-versa is governed by these parameters. For instance, the flux of sulphate from the formation to the borehole counter-balanced its transformation into sulphide in the borehole and a correct mass balance calculation could be achieved only by considering this diffusive flux.

(ii) Knowledge of the undisturbed porewater composition. This composition was established by modelling work using data obtained from other boreholes. This composition represents the initial and the boundary condition of the system to which all of the perturbation is scaled.

(iii) A scenario or set of scenarios describing the bacterial activity as a function of time in the borehole. This scenario must be represented as a sum of different reactions (governed by kinetics) in order to be implemented in the calculation code.

With respect to point (iii), it was not within the scope of this study to try and develop a mechanistic biological model because the biological processes identified were highly nonlinear, due to different phases of bacterial growth and activity as a function of time. For this reason, only the main reaction pathways identified (e.g., acetate production, sulphate reduction and methanogenesis), were introduced in the model without consideration of intermediate reactions. Similarly, it was not possible to attribute one given chemical reaction to one given bacterial strain and to relate it to its abundance as a function of time. The main interest of the modelling exercise was to reproduce the effects (i.e., concentration changes, precipitation or dissolution of minerals) induced by the bacterial activities but not the bacterial activity itself.

\section{Main conclusions from the PC experiment}

\subsection{Evidence \& quantification of diffusion processes}

The behaviour of the conservative tracers HDO and $\mathrm{Br}$ observed in the circulation water and the rock shows that their transport is controlled by diffusion in the clay formation. 
The derived pore diffusion coefficients from 1D radial diffusion modelling parallel to the bedding planes are about 1 and $4 \times 10^{-11} \mathrm{~m}^{2} / \mathrm{s}$ for $\mathrm{Br}$ and HDO respectively, which is consistent with diffusion data for Opalinus Clay (Van Loon et al., 2004a \& 2004b, Wersin et al., 2008). Modelled diffusion porosities (Tournassat et al., 2010; this issue) were consistent with water content and leaching data (Koroleva et al., 2010; this issue) which indicated water loss porosities of $\sim 0.18$ (volume fraction) and anion porosities ("geochemical" porosity according to Pearson, 1999) of about $75 \%$ of this value. This is considerably higher than determined on core samples from other Mont Terri boreholes, in which 50 to $60 \%$ of the total porosity was accessible to anions (Pearson et al., 2003). The fact that anion accessible porosity is less than total porosity is attributed to anion exclusion from the negatively charged clay surface. This difference, as well as the slightly increased total porosity at the borehole rim, suggests a slight disturbance of the micro-fabric around the PC borehole. But, as outlined below, no other changes in the rock were noted.

Diffusion posed a severe constraint for the microbially-mediated redox reactions occurring in the borehole, as indicated also from accompanying modelling study of Tournassat et al. (2010; this issue).

\subsection{Qualitative \& quantitative description of microbial perturbation}

Table 1 illustrates the difference between expected and observed water compositions. The first two compositions correspond to seepage waters from the nearby boreholes BWS-A1 and BPC-C1 where disturbances are much lower than in BPC-1. The log $\mathrm{pCO}_{2}$ values in the seepage waters are lower than -2 , which is consistent with $\mathrm{CO}_{2}$ gas measurements from cores and the porewater extraction laboratory study (Wersin et al., 2010; this issue). The waters in the $\mathrm{PC}$ experiment displayed high $\mathrm{pCO}_{2}$ values of -1.4 to -1.5 which is the result of microbial $\mathrm{CO}_{2}$ production from the degradation of an organic carbon source. 
The main "driver" for this degradation process is fermentation and sulphate reduction, which schematically can be represented as:

$$
2 \mathrm{C}+\mathrm{SO}_{4}{ }^{2-}+2 \mathrm{H}_{2} \mathrm{O} \rightarrow \mathrm{HS}^{-}+2 \mathrm{HCO}_{3}^{-}+\mathrm{H}^{+}
$$

The decrease in sulphate and the concurrent increase in sulphide and alkalinity (Fig. 2) are manifested in the chemistry of the PC waters, which also reveals a decrease in $\mathrm{pH}$ related to the degradation process. The actual reaction pathway turned out to be complex, involving changing DOC concentrations, intermediate organic species and bacterial strains (or physiological groups of bacteria) during the experiment. With the aid of the analyzed data and reactive transport modelling (Tournassat et al., 2010; this issue), the degradation process can be represented by a pathway consisting of four distinct phases of microbial activity (Fig. 3):

During phase 1, only small amounts of organic carbon were released into the borehole water and little bacterial activity and sulphate reduction occurred (lag phase). In phase 2 (which lasted until about 300 days after the start of the experiment) significant amounts of dissolved organic carbon (DOC) appeared in solution. This DOC consisted of various organic acids and other unknown compounds, but contained relatively little acetate at this point. In phase 3 (which lasted until 600 days), the DOC decreased and virtually all of it was transformed to acetate, as shown schematically:

$$
4 \mathrm{C}+\mathrm{SO}_{4}{ }^{2-}+4 \mathrm{H}_{2} \mathrm{O} \rightarrow \mathrm{CH}_{3} \mathrm{COOH}^{-}+\mathrm{HS}^{-}+2 \mathrm{HCO}_{3}{ }^{-}+\mathrm{H}^{+}
$$

The reaction pathway then changed in phase 4, which resulted in a strong decrease in DOC (still composed primarily of acetate) with continuing sulphate reduction. During this last period (phase 4) a strong increase in methane occurred, followed by a slight decrease in methane towards the end of the experiment, suggesting the rising influence of a methanogenic degradation pathway in this stage.

The low solubility of iron-sulphide induced precipitation of x-ray amorphous FeS and subsequent formation of pyrite (observed): 


$$
\begin{aligned}
& \mathrm{Fe}_{\text {rock }}^{2+}+\mathrm{HS}^{-} \rightarrow \mathrm{FeS}+\mathrm{H}^{+} \\
& \mathrm{FeS}+\mathrm{HS}^{-}+\mathrm{H}^{+} \rightarrow \mathrm{FeS}_{2}+\mathrm{H}_{2}
\end{aligned}
$$

The organic degradation process was accompanied by other abiotic side-reactions including release of $\mathrm{Fe}(\mathrm{II})$ from the rock, calcite precipitation and cation and proton exchange reactions at the clay surfaces as deducted from the reaction modelling. These reactions contributed to buffering the chemical conditions in the PC experiment, in particular with regard to $\mathrm{pH}$ and $\mathrm{Eh}$. The relatively stable concentrations of the major cations $\mathrm{Na}^{+}, \mathrm{Ca}^{2+}$ and $\mathrm{Mg}^{2+}$ during the biodegradation process highlights the impact of cation exchange and carbonate dissolution/precipitation processes.

All the geochemically relevant reactions were accounted for in the reactive transport modelling exercise (Tournassat et al., 2010; this issue) on the basis of the conceptual geochemical understanding of the Opalinus Clay (Pearson et al., 2003; Vinsot et al., 2008) and of the geochemically similar Callovo-Oxfordian formation (Gaucher et al., 2009). The main challenge was to simulate the complex kinetic degradation reactions affected by a variable microbial community. This was achieved by assuming simple zero-order reactions (e.g. acetate production, acetate degradation) with fitted reaction rate constants over different time intervals (e.g. acetate production, acetate degradation, methanogenesis), and by testing possible carbon sources (e.g. acetone, glycerol) and their release rates. The observed evolution in general was well-matched by the simulations, especially when glycerol was assumed as the source of the organics (see section below). According to the modelling results (Tournassat et al., 2010; this issue), a total amount of about $5 \mathrm{~g}$ of $\mathrm{FeS}$ (and $5 \mathrm{~g}$ of pyrite) precipitated in the borehole (whose volume is about $3 \mathrm{~L}$ ), the majority of which formed in the borehole water and at the water-clay interface. This is in line with observations of significant amounts of black sulphides (and gold flecks of pyrite) in the PEEK circulation tubes and at the bottom of the borehole, whereas no such products were observed inside the rock. The amount of degrading carbon necessary to produce this sulphide mass depends on the source assumed 
and, according to modelling results, corresponds to about $11 \mathrm{~g}$ of acetone or $17 \mathrm{~g}$ of glycerol leached in the whole volume of the borehole in the course of the experiment (see discussion below). Modelling results indicate that even at its peak, the methane produced represented less than $1 \%$ of the total organic carbon that was degraded during the experiment. Providing that the modelling hypotheses were correct with regard to methane concentration in the formation, this result indicates that methane had very little influence on the carbon mass balance during the experiment.

The results of the microbial analyses of the PC water indicated the presence of a substantial microbial population, with total cell numbers of between $2 \times 10^{8}$ to $7 \times 10^{8}$ cells $/ \mathrm{mL}$, while the active bacterial population was of the order of $6 \times 10^{7}$ cells $/ \mathrm{mL}$ and the active Archaeal population of the order of $3 \times 10^{6}$ cells $/ \mathrm{mL}$. The actually active bacterial population was, therefore, about $10-30 \%$ of the total bacterial population, much higher than usually seen in oligotrophic groundwaters. The culturable heterotrophic aerobic population ranged from about $3 \times 10^{5}$ to $7 \times 10^{6}$ colony-forming units (CFU) per mL, while the culturable heterotrophic anaerobic population ranged from $2 \times 10^{5}$ to $9 \times 10^{5} \mathrm{CFU} / \mathrm{mL}$. The culturable population size for nitrate-, iron-, and sulphate-reducing bacteria ranged from $5 \times 10^{2}$ to $10^{4}$ MPN (most probable number) per mL. These populations are higher than generally found in oligotrophic deep groundwaters, and orders of magnitude higher and more diverse than in undisturbed Opalinus clay. Figure 4 shows the microbial diversity in the PC borehole water at the end of the experiment compared to the diversity in Opalinus clay cores, based on PLFA analysis. Three of the four clay core samples analyzed showed only the presence of normal saturated PLFA, which is present in all organisms. Its presence in high proportions often indicates a less diverse (and likely stressed) population. The PC water in contact with the Opalinus clay showed a much more diverse population with a much smaller percentage of normal saturated PLFA. 
Microbial species identified (with similarity indices between 97 and 100\%) in the pore water (from direct DNA extraction) included Pseudomonas stutzeri, Bacillus licheniformis, Desulfosporosinus sp. and Hyphomonas. Species identified from DNA extractions after enrichment cultures from the overcore samples included Pseudomonas stutzeri, three species of Trichococcus, Caldanaerocella colombiensis, Geosporobacter subterrenus and Desulfosporosinus sp. (Stroes-Gascoyne et al. (2010; this issue). The origin of these (mostly facultative or anaerobic) microbial species cannot be determined with certainty from the data as discussed by Stroes-Gascoyne et al. (2010; this issue). Some species likely resulted from contamination during drilling and some likely from the artificial porewater (not sterilized) that was added to the borehole. Unfortunately, this water was not analyzed for microbial content prior to addition to the PC borehole. However, subsequent batches of artificial water prepared with identical composition showed the presence of a considerable population of heterotrophic microbes (Stroes-Gascoyne and Hamon, 2008; unpublished results). While this does not prove that the artificial porewater added to the PC experiment contained microbes, it supports the suggestion that it likely did. Other species could possibly be revived species indigenous to the Opalinus Clay, although the very old age of the formation (170 Ma) may exclude that (as discussed in Stroes-Gascoyne et al. (2010; this issue), Stroes-Gascoyne et al. (2007).

Regardless of the origin of the microbes, the experience with the PC experiment illustrates that it is very difficult to keep even an in-situ microbiologically almost inactive environment, such as the Opalinus clay formation (Stroes-Gascoyne et al., 2007), from becoming locally active as a result of disturbances. If indigenous dormant organisms are present, some of these can probably be revived if the original formation is disturbed, because such disturbances would provide space, water and nutrients, as could be the case during repository excavation and construction, which almost certainly also will introduce nonindigenous species. 


\subsection{Geochemical buffering by rock}

Contrary to observations in the borehole water, virtually no chemical or mineralogical changes in the adjacent rock were detected. This is explained by the strong buffering effect of the rock and is entirely consistent with results from reactive transport modelling. The rock thus effectively buffers microbially-induced anaerobic redox reactions leading to increased $\mathrm{CO}_{2}$ and alkalinity by carbonate dissolution/precipitation and proton exchange reactions at the clay surfaces. According to the modelling results, a total of about $3 \mathrm{~g}$ of calcite precipitated in the borehole volume or in the surrounding rock resulting from the degradation process, which if distributed across the rock interface, amounts to merely $0.3 \%$ of the initial calcite concentration of the rock at the interface. This supports mineralogical data indicating no changes in calcite content at the interface. Furthermore, the simulations indicate that $\mathrm{pH}$ changes (ranging from 6.7 to 7.0 ) in the porewater are limited to a zone of about $20 \mathrm{~cm}$ within the rock.

The rock also acts as an effective redox buffer and its redox-active species such as siderite, pyrite, $\mathrm{Fe}(\mathrm{II})$ from the clay exchanger, organic matter and to some extent Fe-rich silicates endow it with a large reducing and oxidizing capacity. The main effect of the degradation process on these species was the release of $\mathrm{Fe}(\mathrm{II})$ in the rock and the concomitant precipitation of FeS. The latter process led to a general increase in reducing capacity of the rock close to the water-clay interface.

\subsection{Source(s) of organic carbon}

The identification of the degrading carbon source(s) was one of the main and most challenging issues in the interpretation of the results of the PC experiment, as discussed in detail in De Cannière et al., 2010 (this issue). The results from a laboratory study on materials used in the in-situ experiment that could potentially have degraded during the experiment,

combined with the ${ }^{14} \mathrm{C}$ data shed light on this issue and also evaluated the (in)adequacy of the 
various materials for use in future in-situ tests. The interpretation was aided further by the reactive transport modelling study presented in detail in Tournassat et al. (2010; this issue). The conclusions from this combined set of information are:

- The PE screen and the Teflon-type materials (e.g. PEEK) were shown to be inert and released (almost) no water-soluble compounds.

- The polyamide tubing and polyurethane material used in the packer system released significant amounts of soluble, degradable compounds which, however, were not sufficient to explain the degradation process in the borehole. This was also true for the graphite material released by the EC electrode placed initially.

- Acetone that may have remained in the pores of the PE screen after the cleaning process may have contributed to the fuelling of bacterial activity. The modern signal of the ${ }^{14} \mathrm{C}$ of the DOC and DIC in the water, however, is not consistent with acetone or other material from the packer system as principal degrading agents. Moreover, the modelling exercise showed that a source with the carbon valence of glycerol is the most likely candidate. Also, the amount of acetone residue estimated to remain in the PE screen after cleaning was substantially lower (max. $5 \mathrm{~g}$ of acetone) than the amount required ( $\sim 11 \mathrm{~g}$ of acetone) to reduce the mass of sulphate lost during the experimental period.

- Glycerol, which is highly soluble and degradable, was released from the gel-filling of the reference electrodes immersed in the circulation water. The amount of glycerol in the gel has been analyzed to be $19.5 \%$ of the polymer-filling, i.e. about $1.6 \mathrm{~g}$ of glycerol per electrode (De Cannière et al., 2010; this issue). ${ }^{14} \mathrm{C}$ data and modelling results were in line with glycerol being the main carbon source fuelling microbial activity. The amount required to reduce all of the sulphate in borehole according to modelling results $(\sim 17 \mathrm{~g})$ appears rather high, but is in line with the amount of this compound placed as $\mathrm{pH}$ and Eh electrodes $(\mathrm{pH}$ electrode was replaced twelve times and Eh electrode once, leading to a 
total of 15 gel-filled electrodes emplaced in the circuit, yielding to a total of $\sim 24 \mathrm{~g}$ of glycerol). The other amide-type compounds in the gel display much lower water solubility and degradability relative to glycerol.

- Rock-derived methane is also a potential carbon source, which may fuel SRB in the absence of other organic sources. Indeed, modelling attempts using $\mathrm{CH}_{4}$ as one contributor to the carbon budget were carried out early in the project. However, $\mathrm{CH}_{4}$ together with natural organic matter in the rock is very unlikely as carbon source in view of the ${ }^{14} \mathrm{C}$ results. Moreover, the natural organic matter is known to exhibit low reactivity and degradability (Courdouan et al., 2007).

To conclude, glycerol is the most likely candidate to have fuelled sulphate reduction. Possibly, other sources, such as acetone residues in the PE screen also may have contributed to a lesser extent $(<5 \%)$ to the degradation process.

\subsection{Longer-term effects}

One aspect of particular interest for the safety case of a repository (next section) is the impact of degradable organic material that may be emplaced during the disposal process, on the safety functions of the clay host rock. In this respect, the PC experiment has provided valuable insight on the response of the rock to the effects of microbial degradation of a continuous organic carbon source. The analytical data together with the reactive transport modelling results have highlighted the effective geochemical buffering capacity of the rock, which limits the induced changes to a narrow zone around the degrading source.

One question of interest is the time frame required for restoring initial (or "undisturbed") conditions once the carbon source is depleted. For this purpose, the reactive transport model calibrated with the data obtained from the extensive PC analysis was applied under the assumption that no more carbon (i.e., glycerol) was released after the five years experiment. The main results of this modelling exercise are illustrated in Fig. 5. The model 
predicts that ten years after the end of bacterial perturbation, the system is not completely restored. In particular, redox conditions are still significantly affected $(\Delta \mathrm{pe}>0.2)$ at distances $>1 \mathrm{~m}$ from the borehole. This is due to the diffusion of remaining $\mathrm{S}(-\mathrm{II})$ species $\left(\mathrm{H}_{2} \mathrm{~S}\right.$ and $\mathrm{HS}^{-}$) from the production location (the borehole) into the rock. However, there is large uncertainty relative to this aspect because the kinetics of pyrite precipitation in the formation were not considered for these simulations. Precipitation of pyrite would drastically lower the S(-II) concentrations to levels comparable with the concentration in the undisturbed porewater. Sulphate concentration, $\mathrm{pH}$ and alkalinity values have been almost restored after 15 years due to out-diffusion of $\mathrm{H}_{2} \mathrm{CO}_{3}, \mathrm{HCO}_{3}{ }^{-}$and in-diffusion of $\mathrm{Ca}$, leading to a calcite precipitation front at the borehole/formation interface. This calcite precipitation should lead to decrease of $\mathrm{pH}$ in the borehole but is buffered by the dissolution of calcite in the formation, just behind the interface (see Fig. 5, bottom right).

These simulations together with observations of over-core samples are convincing evidence and confirmation of the high $\mathrm{pH}$ buffer capacity of the Opalinus clay formation.

\subsection{Remaining uncertainties}

The details of the complex biodegradation process involving temporally and probably also spatially variable reaction pathways and microbial populations in the PC experiment could be unravelled only partially. Moreover, the redox conditions in the borehole were affected by the sampling procedures and several experimental disturbances. Hence, for the reactive transport model, simplified empirical kinetic reaction rates, with rate constants fitted to the data, were formulated. There is thus considerable conceptual uncertainty underlying the modelling results. Further uncertainty arises from the model assumptions about mineral reactants in the clay, such as the source for released iron, which ended up in the iron sulphide. The precipitation process of this iron sulphide is another major uncertainty. In particular, the kinetics of pyrite precipitation in the clay, which affected the influence zone of the perturbation according to modelling data. 
As indicated by the modelling results, the main reactions buffering the porewater $\mathrm{pH}$ were carbonate dissolution / precipitation and proton exchange reactions at the clay surfaces. There is uncertainty with regard to the reactivity of silicate phases in response to microbial perturbation because of uncertainty in the thermodynamic and kinetic data associated with these phases. However, because solubility and reaction rates are low under the near-neutral $\mathrm{pH}$ conditions encountered ( $\mathrm{pH}$ ranging from 6.7 to about 7.5 ), dissolution of silicates probably contributed less to $\mathrm{pH}$ buffering than the carbonate and proton reactions.

While the origin of the organic $\mathrm{C}$ source was resolved, the origin of the microbes found in the PC experiment could not be determined with certainty (Stroes-Gascoyne et al., 2010 (this issue)). Contamination during drilling and especially from the artificial porewater cannot be ruled out and is in fact likely (section 3.2). Indigenous organisms are also a possibility: An extensive study was carried out to investigate the occurrence of indigenous microbes and their community size and structure Opalinus Clay cores drilled with aseptic techniques (Mauclaire et al., 2007, Stroes-Gascoyne et al., 2007, Poulain et al., 2008). The results from this study provided limited evidence that a small, viable but most likely largely dormant, microbial community is present in Opalinus Clay, which was corroborated by a second, much more limited set of analyses (Stroes-Gascoyne et al., 2008), on large diameter Opalinus Clay cores, drilled using air-cooling. The microbial characterization of Opalinus Clay suggested that unperturbed Opalinus Clay contains only a small viable microbial community, which is probably metabolically (almost) inactive (i.e., dormant cells and spores), due to water, space and nutrient restrictions. It is not possible to determine how old such surviving species might be. The Opalinus Clay formation is $170 \mathrm{Ma}$ old, but survival of microbes (in spore or dormant form) beyond 0.6 to $3 \mathrm{Ma}$, in ancient geological formations, is currently being disputed. Another possible source of indigenous microbes, therefore, could be a recent $(<3 \mathrm{Ma})$ intrusion of water into the Opalinus Clay formation, although this appears unlikely. Stroes-Gascoyne et al. (2010; this issue) discuss these possibilities in more detail. 


\section{$4 \quad$ Implications for repository safety}

\subsection{The multi-barrier concept \& assessment of long-term safety}

Deep geological disposal relies on effective isolation of the high-level nuclear waste (HLW) from the human environment for very long time periods (i.e. $10^{5}-10^{6}$ years). This long time period is required for the radiotoxicity of the waste to reach acceptable levels resulting from radioactive decay (e.g. Andra, 2005). The geological disposal of HLW is based on the multi-barrier concept, acknowledging the difficulty of assuring complete isolation of the waste for such long timescales. Thus, the disposal system is designed to retard and to attenuate the releases of decaying radionuclides through various barriers in the engineered system (i.e., low-solubility waste matrix, corrosion-resistant metal waste containers, lowpermeability backfilling material) and the hydrologically isolating surrounding natural system (host rock). A simplified sketch of the main safety barriers in the Swiss HLW disposal concept is illustrated in Fig. 6. The geological clay-stone barrier, i.e. the $50 \mathrm{~m}$ thick layer of Opalinus Clay below and above the HLW repository, plays a central role in this disposal concept, as outlined more in detail below.

The implementation of a HLW waste repository is a complex and lengthy process necessitating, apart from the delicate political decisions and societal efforts, a staged approach with an advanced scientific and technical programme. A key aspect in this programme is longterm safety, which needs to be addressed in a thorough, transparent and traceable manner. In view of the extensive experience with this issue gained in the various international nuclear waste management programmes, procedures for evaluating long-term safety have been established. Thus, rather than presenting a set of radionuclide transport- and resulting dosecalculations, as was often the strategy 20 to 30 years ago, a comprehensive safety case is presented. According to the Nuclear Energy Agency of OECD (NEA, 2004), "A safety case is 
the synthesis of evidence, analyses and arguments that quantify and substantiate a claim that the repository will be safe after closure and beyond the time when active control of the facility can be relied on." Important elements of the safety case are: the safety concept (e.g. description of disposal system components and their safety functions), the assessment basis (e.g. methods, models, scientific \& technical data for different repository components and geosphere), evidence, analyses and arguments (e.g. quantitative analyses, such as radionuclide transport calculations and qualitative safety arguments), and a synthesis (overall interpretation of all safety-relevant considerations).

The safety case strategy generally can be applied to different geological disposal concepts, but the relevance of the different repository components to safety is of course siteand concept-specific. Hence, the safety functions need to be defined and evaluated for each safety barrier within a given disposal system, also taking into account possible interactions between the different system components and perturbation scenarios. A common procedure for this is to systematically consider all possible factors which could affect the safety functions of a safety barrier with the aid of a so-called FEP (features, events and processes) catalogue (NEA, 2000).

\subsection{The role of the claystone barrier in the safety case}

As noted above, the argillaceous host rock is a central part of the safety concept for a number of current HLW disposal systems. Its main safety functions are (e.g. Nagra, 2002) (1) to confine the waste and to protect the engineered barriers by its low permeability, mechanical stability and favourable geochemical properties; and (2) to attenuate releases of radionuclides by retardation and slow diffusion processes. The FEPs, which may affect the safety functions of the clay host rock, have been evaluated by an international working group of NEA and reported in Mazurek et al. (2003). These FEPs are compiled in a hierarchically structured list, a simplified and adapted version of which is presented in Table 2. In the first order 
structuring, FEPs are separated for the "undisturbed" clay system and for the clay system "perturbed" by repository-induced or external (not shown in Table 2) effects (such as glaciations for instance).

In the PC experiment, FEPs from both the undisturbed and perturbed clay system have been addressed as well as the linked processes between these. The FEPs addressed for the PC experiment are given in Table 2, and the most relevant ones highlighted in blue.

\subsection{Concept of geochemical stability in clay host rocks}

Geochemical stability is one of the principal characteristics of argillaceous rocks, and initially attracted interest in them as possible host rock formations. One property that gives rise to this stability is a diffusion-only transport regime, which limits the flux of materials from the interior of such formations to their boundaries. A second attractive property is that the dominant amounts of reactive and others solutes are associated with the reactive solids in the formation itself rather than with the pore waters. The formation solids buffer the pore water chemical composition including such properties as $\mathrm{pH}$ and redox potential.

The slow response of systems in which diffusion dominates can be demonstrated by two studies at Mont Terri. The first considered the regional distribution of pore-water chloride concentrations (illustrated in Figure 2 of Wersin et al., 2010; this issue). This pattern can be simulated by modelling diffusion from the Opalinus and adjacent Liassic clays into overlying and underlying aquifers. A detailed analysis of this profile was provided by Mazurek et al. (2009). The basis of the conceptual model is that the clays and surrounding units initially had a uniform chloride content throughout. As fresh water began to flow in adjacent aquifers, outdiffusion from the clay began. The times at which this fresh-water flow began could be fitted to the measured chloride profiles. The asymmetric shape of the profile indicated that freshwater had been present in the overlying Malm aquifer longer than in the underlying Keuper aquifer. Adjusting the times in the modelling for a best fit indicated opening of the Malm aquifer at about $6.5 \mathrm{Ma}$ and of the Keuper at $0.5 \mathrm{Ma}$, if an initial concentration of $19 \mathrm{~g}$ 
chloride per litre was present, i.e., that of seawater. If an initial concentration of $15 \mathrm{~g}$ chloride per litre was assumed, slightly above $13.9 \mathrm{~g}$ chloride per litre, the highest measured value, the corresponding times for the opening of the aquifers were similar, i.e., 4.4 Ma and 0.4 Ma. These times correspond very well with the times at which the upper and lower aquifers were first breached during erosion of the Jura Mountains, so that freshwater circulation could begin.

The PC experiment itself supports the slow response of the Clay system, although on a much smaller spatial and much shorter time scale than the regional studies by Mazurek et al. (2009).

The second aspect that confirms geochemical stability is the high buffering capacity of clay rocks. As Pearson et al. (2010; this issue) and Tournassat et al. (2010; this issue) showed, the water chemistry was controlled by such water-rock reactions as cation exchange and mineral equilibria. Chloride and bromide are present only in the pore water. Sulphate is found sporadically in the Opalinus Clay as celestite in veins but it is not clear whether the pore water is in equilibrium with this mineral (Pearson et al., 2010; this issue). All other solutes can be related to cation exchange or mineral equilibria and $99 \%$ or more of the total mass of each of these elements is present in the solid phase as minerals or bound to minerals surfaces rather than in the pore water, except for sodium of which about $88 \%$ is in the rock. Thus, the capacity of the rock to buffer changes in bulk water chemistry is very high.

In modelling porewater $\mathrm{pH}$ values, several reactions have been used including carbonate and silicate reactions and $\mathrm{pH}$ buffering by clay surfaces. As discussed in Pearson et al., 2010 (this issue), reactions among carbonate species $\mathrm{CO}_{3}{ }^{2-}, \mathrm{HCO}_{3}{ }^{-}$and $\mathrm{CO}_{2(\mathrm{aq})}$ can be associated with solution electroneutrality and so establish the $\mathrm{pH}$. Reactions among silicate minerals such as kaolinite chlorite and illite can also buffer $\mathrm{pH}$. Large amounts of carbonate and silicate minerals are present within the Opalinus Clay. Moreover, the clay surfaces display a large proton exchange capacity, i.e. protonation and deprotonation reactions at the variably 
charged surfaces, depending on $\mathrm{pH}$ conditions contribute substantially to the overall $\mathrm{pH}$ buffering capacity and $\mathrm{pH}$ buffering is included in the reaction modelling in Tournassat et al., 2010 (this issue) as an influence on the chemistry of water in the borehole.

\subsection{Microbiological perturbations and their effects on safety functions}

The need to consider the effects of microbial metabolism on geochemical conditions in the deep subsurface in relation to a future repository for HLW is a relatively new concept, stemming from the mid 1980's (e.g., West and McKinley, 1984, West et al., 1985). It has been an element of investigations made to assess the safety of potential repositories since that time. Microbial activity in a HLW repository is of concern for a number of reasons (e.g., Stroes-Gascoyne and West, 1996), one of which is their effect on Eh and pH. Specifically, the likely scenario in the PC experiment contained the following elements: Microbial organotrophic metabolism (fed by glycerol) caused the production of $\mathrm{CO}_{2}$ (and $\mathrm{H}_{2} \mathrm{O}$ ), which increased the $\mathrm{pCO}_{2}$ in a system, leading to a drop in $\mathrm{pH}$ and a potential increase in the mobility of radionuclides, because most radionuclides are least soluble at neutral $\mathrm{pH}$ values. The continued microbial breakdown of organic matter rapidly depleted any $\mathrm{O}_{2}$ in the system, after which the microbial metabolism switched to fermentation, which then produced the low$\mathrm{C}$ fatty acids that are required for heterotrophic sulphate-reducing bacteria activity. The products of the sulphate reduction are observed reduced sulphur species including sulphide, which is a well-known corrosion agent for both copper and steel waste containers.

However, the intense effects of the microbial disturbances seen in the PC experiment were of a relative short duration. In a repository setting, the time frame of possible disturbances would largely depend on the size and duration of the disturbance, i.e., how much organic material, water and space were introduced and where. Once introduction stops and nutrients have been used up, the system can only be fed through nutrients that are present in the formation itself. In situ metabolism would then be limited by the diffusion kinetics of such nutrients to places where microbial activity is possible (i.e., where adequate porespace and 
water are present, either in localities naturally existing in the clay formation or induced by excavation processes such as for instance the excavation damage zone (EDZ)). Microbial metabolism not enhanced by disturbances is likely very limited and slow in the tight undisturbed Opalinus Clay formation, leaving most microbes in a dormant state, which can only be activated through such disturbances as evident in the PC experiment. The actual occurrence of a very low level metabolism in pristine undisturbed Opalinus clay is at present a hypothesis only and has, thus far, not been confirmed or measured.

\subsection{Discussion \& outlook}

The unintentional placement of degradable organic carbon source, which resulted in anaerobic microbial perturbation of the PC experiment, has contributed significantly to the understanding of potential biogeochemical processes in Opalinus Clay. In particular, similar perturbations could occur in zones disturbed by excavation (EDZ) where porosities are increased and microbial activity could take place. The results of the PC experiment highlighted the significant potential for SRB activity in Opalinus clay that could be realized as a result of disturbance of the system. Sulphate reduction is accompanied by an increase in $\mathrm{pCO}_{2}$ and alkalinity, and a decrease in $\mathrm{pH}$ and Eh relative to the undisturbed porewater. Biodegradation moreover produces low molecular weight organic acids with concentrations that may be highly variable and are presumably affected by methanogenic reactions. The reaction pathways are complex and dependent on many site-specific parameters, and are not yet understood in detail. The origin of the bacteria fuelling degradation is not clear, but for safety considerations, this is not a relevant issue because the same processes by which bacteria could have been introduced into the PC borehole would be expected to occur during repository construction and operation. Furthermore, the large amount of participating dissolved and solid reactants from the clay complicates the quantitative description of the biogeochemical processes. Consequently, uncertainties from quantitative modelling of biodegradation are still rather large, especially with regard to the predictive use of the model. 
In summary, the results from the PC experiment are a valuable contribution with respect to the safety case. Any geochemical changes induced by anaerobic microbial perturbation, should they occur, would affect the solubility and sorption behaviour of radionuclides eventually released from the engineered system. Also, the production of reduced sulphur species, such as sulphide may adversely affect corrosion of the metal waste overpacks. This emphasizes that the amount of organic compounds emplaced in a HLW repository should be limited as much as possible to avoid such effects. Nevertheless, it should be noted that many of the large solute changes observed in the PC experiment were of a transient nature (e.g. elevated $\mathrm{HS}^{-}$or DOC levels) and decreased again rather rapidly (on a repository time scale). The changes in $\mathrm{pH}$ and Eh conditions were quite significant, but not dramatic with regard to repository safety. The large buffering capacity of the clay as well as its diffusive properties are effective in limiting geochemical gradients in the porewater and also the geochemical and mineralogical changes induced by the microbial disturbance. As suggested also by modelling, restoration times to achieve natural or background conditions are expected to be rather short once the degradable sources have been depleted.

The experiment also highlighted the fact that equipment materials commonly used in in-situ tests do not always display the commonly assumed inert behaviour. This particularly holds for gel-type "robust" reference electrodes, which may release substantial amounts of glycerol. The assessment of potential experimental artefacts should always be a part of the overall analysis of the results of large in-situ tests.

\section{Acknowledgements}

This work was carried out within the Mont Terri Project in close co-operation with the

Mont Terri Consortium. We especially appreciate the support of Thomas Fierz (Solexperts), Pierre De Cannière and Hugo Moers (SCK-CEN), Urs Mäder (Uni Bern), Bernd Frieg (Nagra), Paul Bossart, Christophe Nussbaum, Heinz Steiger, Olivier Meier (Geotechnical 
Institute / Swisstopo) and the COREIS and Schützeichel teams for the field work. The support of Lorenz Eichinger (Hydroisotop) for the analytical work is acknowledged. The manuscript has benefited from many fruitful discussions with scientists within and outside the team of the PC experiment. S. Stroes-Gascoyne thanks the Nuclear Waste Management Organisation in Canada for funding her contribution to this work.

\section{References}

Andra, 2005. Dossier 2005 Argile.

Beaucaire, C., Pearson, F.J., Gautschi, A., 2004. Chemical buffering capacity of clay rock. In Stability and buffering capacity of the geosphere for long-term isolation of radioactive waste, "Clay Club" Workshop Proceeedings, Braunschweig, Germany, 9-11 December 2003, OECD 2004, NEA No. 5503, pp. 147-154.

Courdouan, A., Christl, I., Meylan, S., Wersin, P., Kretzschmar, R., 2007. Characterization of dissolved organic matter in anoxic rock extracts and in situ pore water of the Opalinus Clay. Applied Geochemistry 22, 2926-2939.

De Cannière, P., Schwarzbauer, J., Höhener, P., Lorenz, G., Salah, S., 2010. Biogeochemical Processes in a Clay Formation In-situ Experiment: Part C- Organic contamination and leaching data. Applied Geochemistry (this issue).

Gaucher, E.C., Tournassat, C., Pearson, F.J., Blanc, P., Crouzet, C., Lerouge, C., Altmann, S., 2009. A robust model for pore-water chemistry of clayrock. Geochim. Cosmochim. Acta $73,6470-6487$.

Koroleva, M., Lerouge, C., Mäder, U., Claret, F., Gaucher, E.C., 2010. Biogeochemical Processes in a Clay Formation In-situ Experiment: Part B - Insights and data from the overcoring of a microbially perturbed in-situ pore water chemistry experiment - evidence of strong buffering by the rock formation. Applied Geochemistry (this issue).

Mäder, U., 2004. Porewater Chemistry (PC) Experiment: A new method of porewater extraction from Opalinus Clay with results for a sample from borehole BPC-A1. Mont Terri Project Technical Note TN2002-25.

Mauclaire, L., McKenzie, J.A., Schwyn B. and Bossart, P., 2007. Detection and cultivation of indigenous microorganisms in Mesozoic claystone core samples from the Opalinus Clay Formation (Mont Terri Rock Laboratory). Physics and Chemistry of the Earth 32, 232240.

Mazurek, M., Alt-Epping, P., Bath, A., Gimmi, T., and Waber, H. N., 2009. Natural Tracer Profiles Across Argillaceous Formations: The CLAYTRAC Project. Paris, Nuclear Energy Agency, OECD, 361 p.

Mazurek, M., Pearson, F.J., Volkaert, G., Bock, H., 2003. Features, events and processes evaluation catalogue for argillaceous media. OECD / NEA, Paris. 
Nagra, 2002. Project Opalinus Clay, demonstration of disposal feasibility for spent fuel, vitrified high-level waste and long-lived intermediate-level waste, safety report, NTB Technical Report 02-05, Wettingen, Switzerland

NEA, 2000. Features, events and processes (FEPs) for disposal of radioactive waste - an international database. OECD /NEA, Paris.

NEA, 2004. Post-closure safety case for geological repositories, nature and purpose. OECD / NEA, Paris.

Pearson, F.J., 1999. What is the porosity of a mudrock? In: Muds and Mudstones: Physical and fluid flow properties. Aplin A.C., Fleet A.J., Macquaker J.H.S. (eds.). Geological Society, London, Special Publications. 158, 9-21.

Pearson, F.J., Arcos, D., Bath, A., Boisson, J.Y., Fernández, A.M., Gäbler, H.-E., Gaucher, E., Gautschi, A., Griffault, L., Hernán, P., Waber, H.N., 2003. Geochemistry of water in the Opalinus clay formation at the Mont Terri Rock Laboratory. Federal Office for Water and Geology, Bern, Series No. 5.

Pearson, F.J., Tournassat, C., Gaucher, E., 2010. Biogeochemical Processes in a Clay Formation In-situ Experiment: Part E - Equilibrium controls on chemistry of pore water from the Opalinus Clay, Mont Terri Underground Laboratory, Switzerland. Applied Geochemistry (this issue).

Poulain, S., Sergeant, C., Simonoff, M., Le Marrec, C., Altmann, S., 2008. Microbial investigation of Opalinus Clay, an argillaceous formation under evaluation as a potential host rock for a radioactive waste repository. Geomicrobiology Journal, 25(5): 240-249.

Stroes-Gascoyne, S. and West, J.M., 1996. An Overview of Microbial Research Related to High-Level Nuclear Waste Disposal With Emphasis on the Canadian Concept for the Disposal of Nuclear Fuel Waste. Canadian Journal of Microbiology 42, 349-366.

Stroes-Gascoyne, S., Schippers, A., Schwyn, B., Poulain, S., Sergeant, C., Le Marrec, C., Simonoff, M., Altmann, S., Nagaoka, T., Mauclaire, L., McKenzie, J., Daumas, S., Vinsot, A., Beaucaire, C., Matray J.M., 2007. Microbial community analysis of Opalinus Clay drill core samples from the Mont Terri Underground Research Laboratory, Switzerland. Geomicrobiology 24, 1-17.

Stroes-Gascoyne, S., Sergeant, C., Schippers, A., Hamon, C.J., Nèble, S., Vesvres, M.-H., Poulain, S., Le Marrec., C., 2008. Microbial analyses of PC water and overcore samples: Synthesis of results. Mont Terri Project Technical Note TN2006-69, Bern (CH).

Stroes-Gascoyne, S., Sergeant, C. Schippers, A., Hamon, C.J., Neble, S., Vesvres, M.-H., Barsotti, V., Poulain, S., Le Marrec. C., 2010. Biogeochemical Processes in a Clay Formation In-situ Experiment: Part D - Microbial analyses of the Porewater Chemistry experiment at the Mont Terri Rock Laboratory - Synthesis of results. Applied Geochemistry (this issue).

Tournassat, C., Alt-Epping, P., Gaucher, E.C., Gimmi, T., Leupin, O.X., Wersin, P., 2010. Biogeochemical Processes in a Clay Formation In-situ Experiment: Part F - Reactive transport modelling. Applied Geochemistry (this issue).

Van Loon, L.R., Soler, J.M., Müller, W., Bradbury, M.H., 2004a. Anisotropic diffusion in layered argillaceous rocks: a case study with Opalinus Clay. Env. Sci. Technol. 38, 57215728. 
Van Loon, L.R., Wersin, P., Soler, J.M., Eikenberg, J., Gimmi, Th., Hernán, P., Dewonck, S., Matray, J.-M., 2004. In-situ diffusion of HTO, ${ }^{22} \mathrm{Na}^{+}, \mathrm{Cs}^{+}$and $\mathrm{I}^{-}$in Opalinus Clay at the Mont Terri underground rock laboratory. Radiochimica Acta 92, 757-763.

Vinsot, A., Appelo, C.A.J., Cailteau, C., Wechner, S., Pironon, J., De Donato, P., De Cannière, P., Mettler, S., Wersin, P., Gäbler, H.-E., 2008. $\mathrm{CO}_{2}$ data on gas and porewater sampled in situ in the Opalinus Clay at the Mont Terri rock laboratory. Physics and Chemistry of the Earth 33, S54-S60.

Wersin, P., Soler J.M., Van Loon, L., Eikenberg, J., Baeyens, B., Grolimund, D., Gimmi, T., Dewonck, S. 2008. Diffusion of HTO, $\mathrm{Br}^{-}, \mathrm{I}^{-}, \mathrm{Cs}^{+},{ }^{85} \mathrm{Sr}^{2+}$ and ${ }^{60} \mathrm{Co}^{2+}$ in a clay formation: Results and modelling from an in situ experiment in Opalinus Clay. Applied Geochemistry 23, 678-691.

Wersin, P., Leupin, X.O., Mettler, S., Gaucher, E., Mäder, U., Vinsot, A., De Cannière, P., Gäbler, H. E., Kunimaro, T., Kiho, K., 2010. Biogeochemical Processes in a Clay Formation In-situ Experiment: Part A - Overview, experimental design and water data, Applied Geochemistry (this issue).

West, J.M., and McKinley, I.G., 1984. The geomicrobiology of nuclear waste disposal. Mat. Res. Soc. Symp. Proc. 26 (Scientific Basis for Nuclear Waste Management VII), 487-494.

West, J.M., Christofi, N., and McKinley, I.G., 1985. An overview of recent microbiological research relevant to the geological disposal of nuclear waste. Rad. Waste Managem. Nucl. Fuel Cycle 6, 79-95. 


\section{Figure captions}

Figure 1 Sketch of the geological profile and the Mont Terri Rock URL (upper) and location of the PC experiment (lower). Location of boreholes cited in text also shown.

Figure 2 Evolution of the dissolved sulphate, alkalinity and sulfide concentrations in borehole of PC experiment as function of time.

Figure 3 Measurement of organic compounds as a function of time $($ TOC $=$ total organic carbon, $\mathrm{DOC}=$ dissolved organic carbon) and suggested phases of microbial degradation (see text).

Figure 4 Relative percentage of Total PLFA structural groups in Opalinus cores drilled with $\mathrm{N}_{2}$ (1751 and 1757), in the PC clay overcore (near the borehole (1762 Inner) and further away from the borehole (1762 outer) and in the PC borehole water after termination (1754). Structural groups are assigned according to PLFA chemical structure, which is related to fatty acid biosynthesis.

Figure 5 Results of predictions from reactive transport model. This model was used to predict the biogeochemical evolution in the borehole and the adjacent rock of the PC experiment with glycerol as carbon source (Tournassat et al. 2010; this issue). 5 years: simulation results at the end of experiment with degrading glycerol. 10, 15 years: prediction results under assumption that no more bacterial activity occurs. The borehole with the circulating fluid are still in contact with the rock and in and out-diffusion from the borehole occurs. Only the formation is represented here.

Figure 6 Components and their safety functions of a repository in the Swiss concept for vitrified high-level radioactive waste disposal (Nagra, 2002). 
Table 1 Selected Water compositions in PC experiment and comparison with seepage water from nearby boreholes

\begin{tabular}{|c|c|c|c|c|c|}
\hline Borehole number & BPC-1 & BPC-1 & BPC-1 & BWS-A1 & BPC-C1 \\
\hline Sample number & PC-0 & PC-6 & PC-12 & A1-85 & \#185378 \\
\hline $\begin{array}{l}\text { Sample } \\
\text { description }\end{array}$ & $\begin{array}{l}\text { Initial synthetic } \\
\text { water before } \\
\text { experiment start }\end{array}$ & $\begin{array}{c}\text { Porewater } \\
\text { composition at } \\
\text { peak DOC conc., } \\
600 \text { days after } \\
\text { start }\end{array}$ & $\begin{array}{c}\text { Porewater } \\
\text { composition at } \\
\text { end, } 1846 \text { days } \\
\text { after start }\end{array}$ & $\begin{array}{c}\text { Porewater } \\
\text { composition } \\
\text { (seepage water) } \\
\text { 28. Apr. } 99\end{array}$ & $\begin{array}{c}\text { porewater } \\
\text { composition } \\
\text { (seepage water) }\end{array}$ \\
\hline $\mathrm{pH}$ & 7.7 & 6.7 & 6.8 & 7.5 & 7.2 \\
\hline $\mathrm{Eh}_{\mathrm{SHE}}(\mathrm{mV})$ & & -227 & -250 & & -- \\
\hline $\log \left(\mathrm{pCO}_{2}\right)^{\mathrm{a}}$ & -2.6 & -1.36 & 1.48 & -2.56 & -2.08 \\
\hline Alk (mM) & 1.0 & 11.4 & 10.4 & 2.5 & 3.3 \\
\hline DOC (mM) & 0.2 & 10.6 & 1.3 & $1.1^{\mathrm{b}}$ & 4.8 \\
\hline $\mathrm{SO}_{4 \text { tot }}(\mathrm{mM})$ & 14.7 & 6.2 & 4.3 & 14.1 & 17.0 \\
\hline $\mathrm{HS}_{\text {tot }}(\mathrm{mM})$ & & 1.0 & 0.4 & & \\
\hline $\mathrm{Cl} \& \mathrm{Br}(\mathrm{mM})$ & 291 & 294 & 285 & 292 & 330 \\
\hline $\mathrm{Na}(\mathrm{mM})$ & 255 & 251 & 243 & 246 & 281 \\
\hline $\mathrm{Ca}(\mathrm{mM})$ & 15.9 & 15.3 & 13.5 & 15.0 & 19.3 \\
\hline $\mathrm{Mg}(\mathrm{mM})$ & 18.0 & 19.0 & 17.1 & 16.9 & 22.3 \\
\hline $\mathrm{C}_{13}$-DIC (\%o) & -29.1 & -16.6 & -11.5 & $-13.1^{b}$ & -7.3 \\
\hline
\end{tabular}

${ }^{\mathrm{a}}$ calculated from Alkalinity \& $\mathrm{pH}$ measurement

${ }^{\mathrm{b}}$ sample taken on Feb. 18, 1998 
Table 2 List of features, processes and events (FEPs) for clay host rocks according to the FEPCAT list (Mazurek et al., 2003) and FEPs relevant with regard the PC experiment, most relevant FEPs addressed by PC in blue

\begin{tabular}{|c|c|}
\hline Structured FEPs classification & FEPs relevant to $\mathrm{PC}$ \\
\hline $\begin{array}{l}\text { UNDISTURBED SYSTEM } \\
\text { Transport mechanisms } \\
\quad \text { Advection/dispersion } \\
\quad \text { Diffusion } \\
\quad \text { Colloid formation, transport and filtration }\end{array}$ & $\mathrm{x}$ \\
\hline $\begin{array}{ll}\text { Retardation mechanisms } \\
\text { - } & \text { Matrix diffusion } \\
& \text { Sorption (broad definition) } \\
\text { Mineralogy of rocks } \\
\text { Natural organics / complexation } \\
\quad \text { Porewater composition (e.g. pH, } \mathrm{pCO}_{2}, \text { Eh) } \\
\quad \text { Dissolution / precipitation } \\
\quad \text { Ion exchange / surface complexation } \\
\end{array}$ & $\begin{array}{l}\mathrm{x} \\
\mathrm{x} \\
\mathrm{x} \\
\mathrm{x} \\
\mathrm{x}\end{array}$ \\
\hline $\begin{array}{l}\text { System understanding } \\
\quad \text { Paleo-hydrogeology of host rock and embedding formations } \\
\text { Evolution of pore-fluid chemistry } \\
\quad \text { Water residence times in host formation } \\
\end{array}$ & $\mathrm{x}$ \\
\hline $\begin{array}{l}\text { REPOSITORY-INDUCED PERTURBATIONS } \\
\text { Chemical and microbiological perturbations } \\
\text { - } \quad \text { Oxidation/reduction of the host rock } \\
\text { - } \quad \text { Changes in } \mathrm{pCO}_{2} \text { and pH } \\
\text { - } \mathrm{pH} \text { buffer capacity of host rock }\end{array}$ & $\begin{array}{l}x \\
x \\
x \\
x\end{array}$ \\
\hline $\begin{array}{l}\text { Thermal perturbations } \\
\text { Geomechanical perturbations }\end{array}$ & \\
\hline $\begin{array}{l}\text { Hydraulic perturbations } \\
\text { Perturbation from coupled processes }\end{array}$ & \\
\hline
\end{tabular}



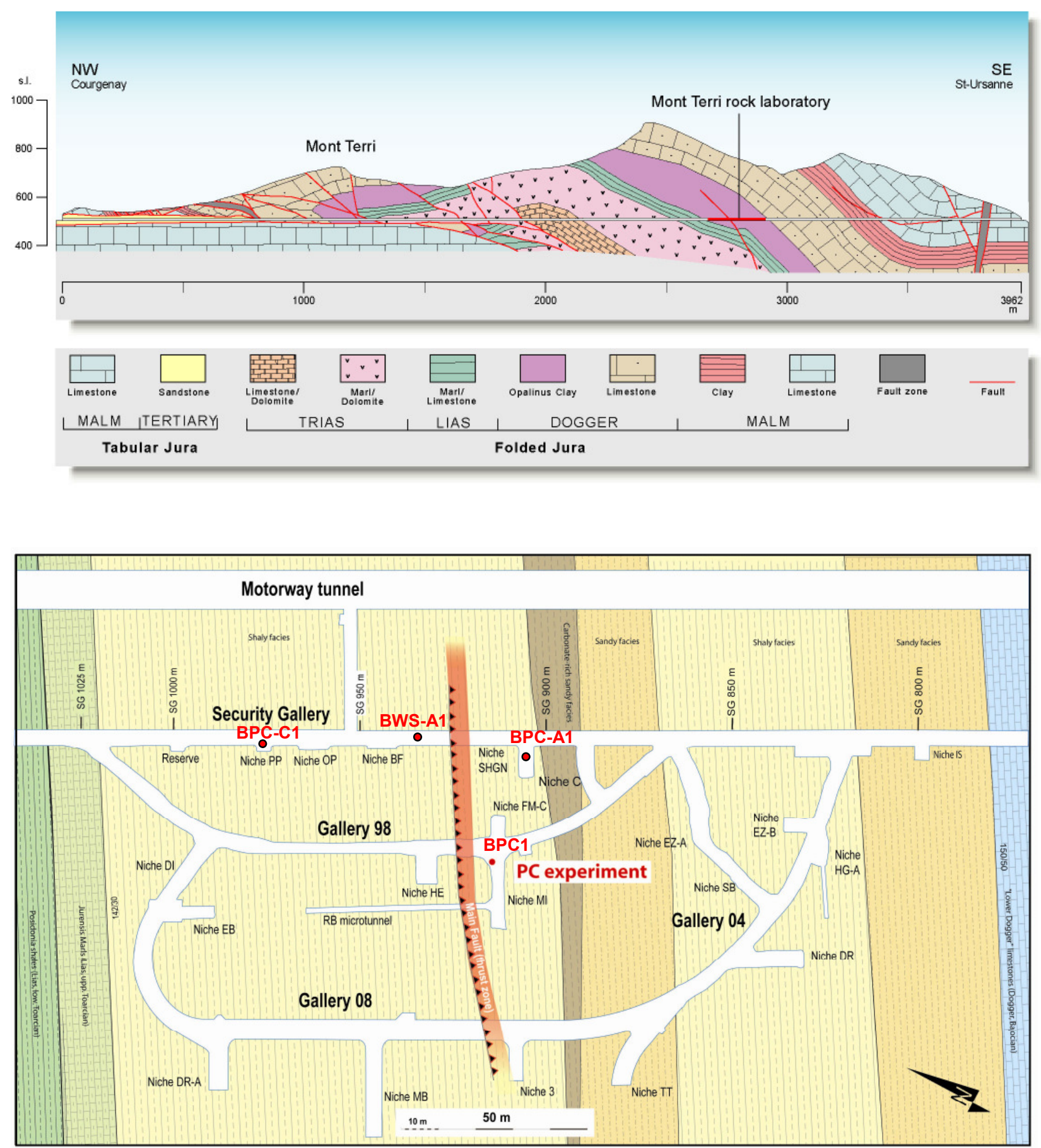

Figure 1 


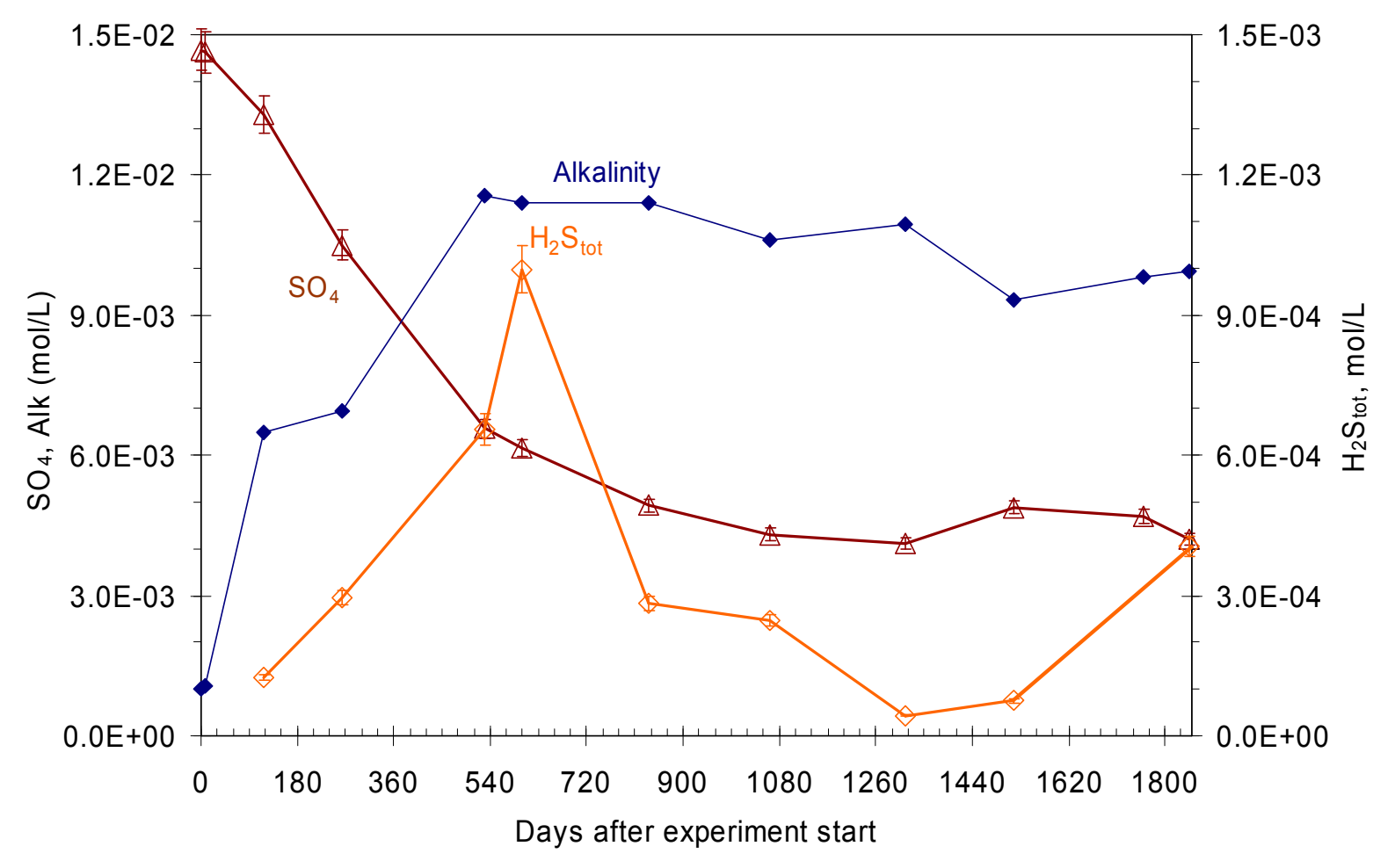

Figure 2 


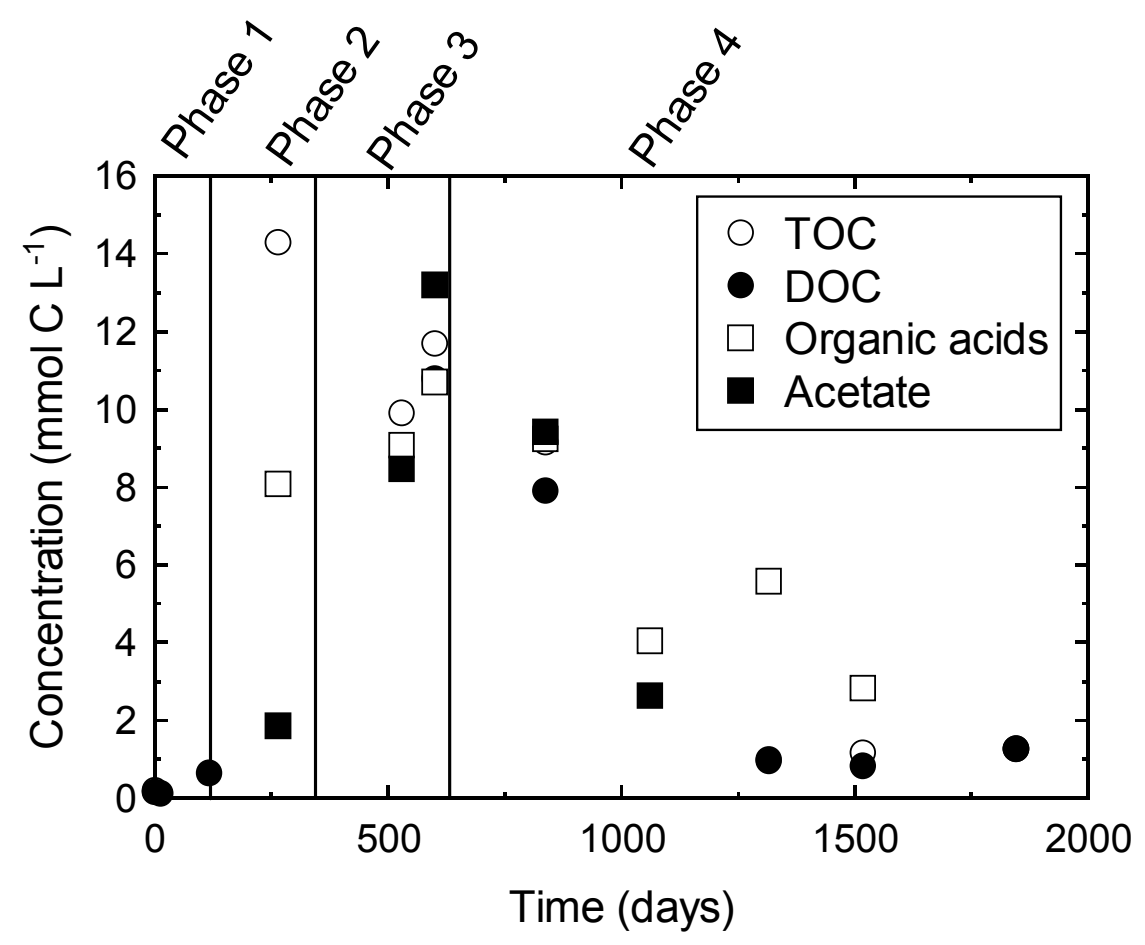

Figure 3 


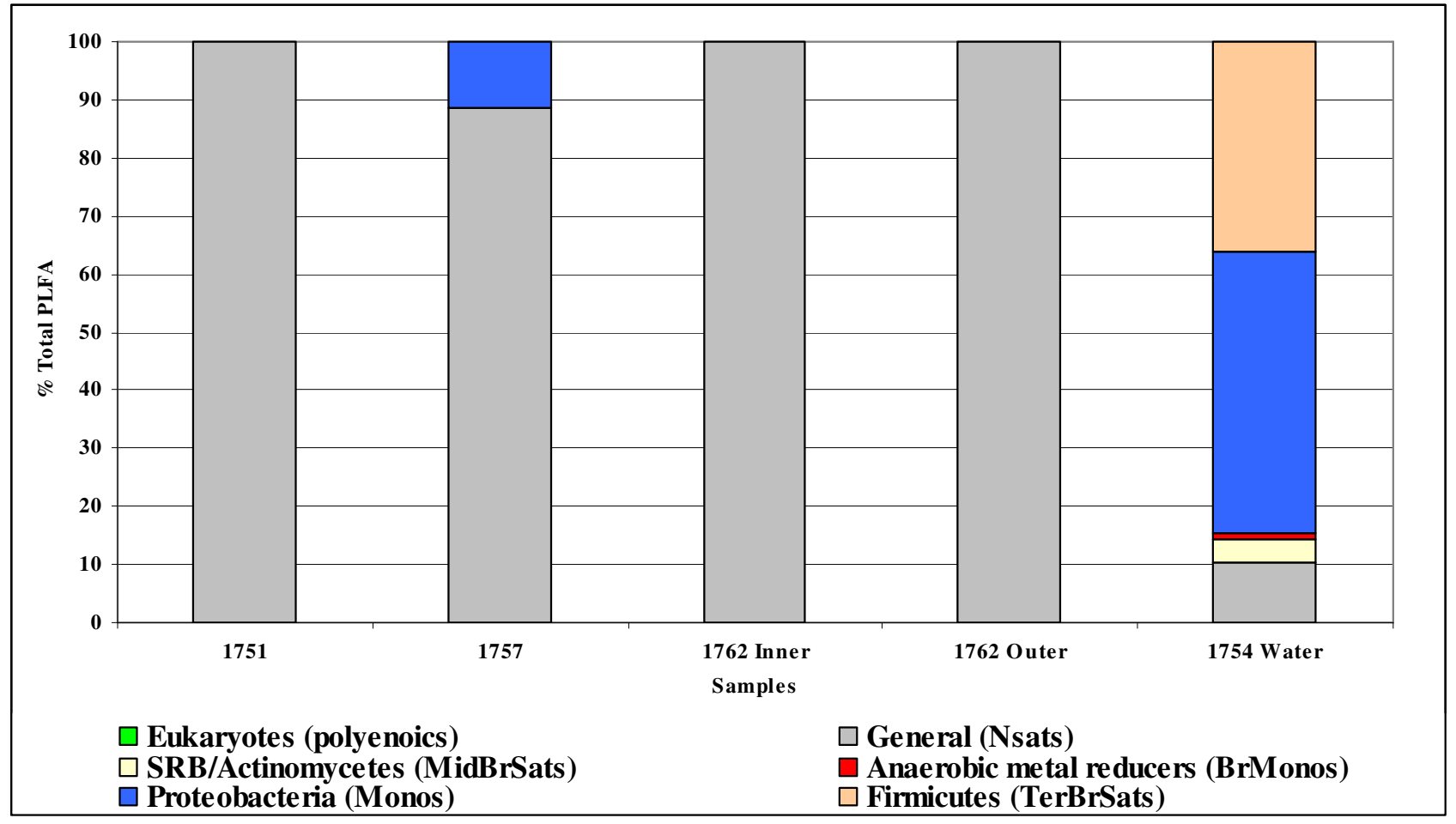

Figure 4 


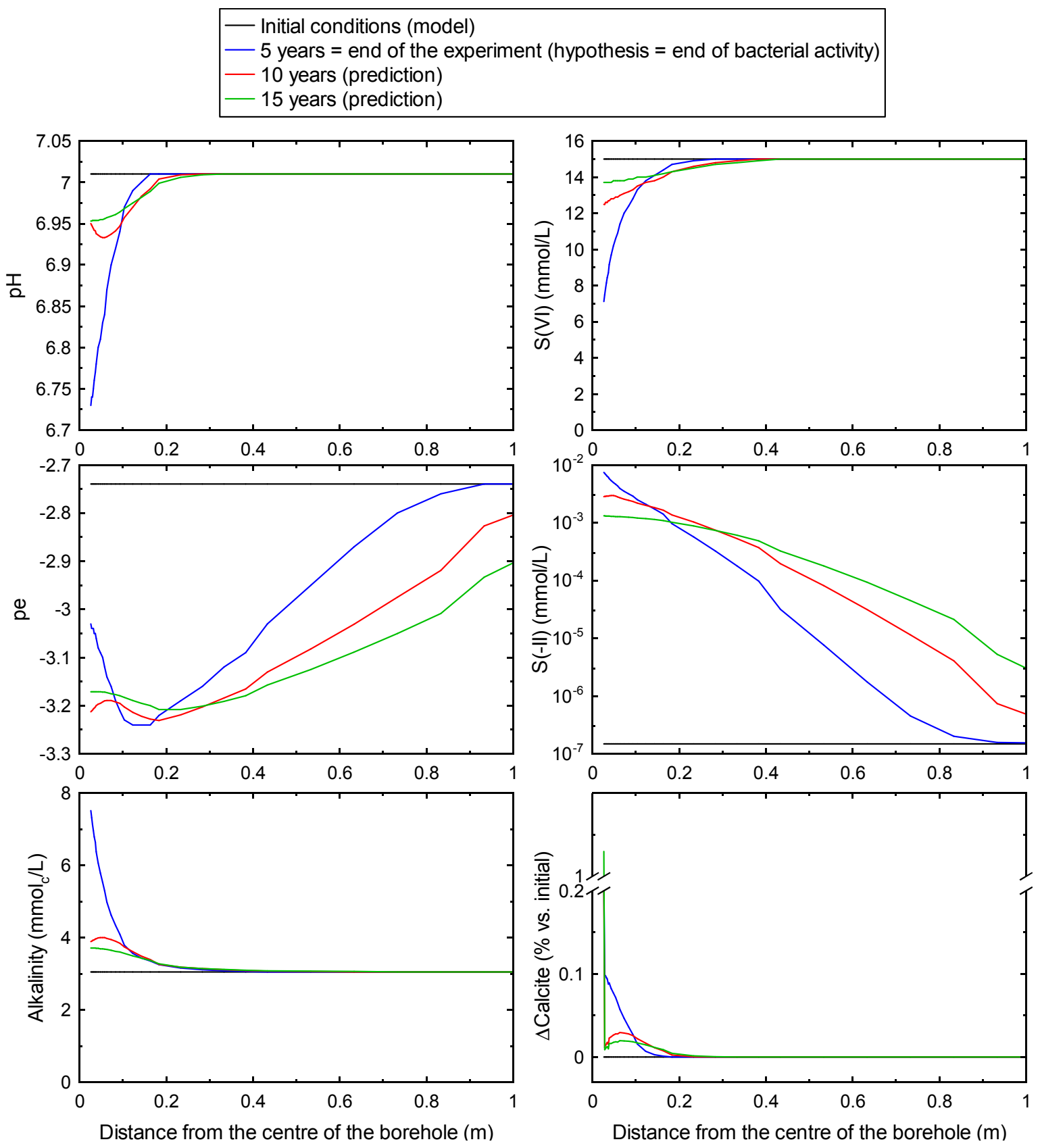

Figure 5 


\section{Safety barrier system for vitrified HLW}

Glass matrix (in steel flask)

- Confinement

- Containment of radionuclides in glass

- Attenuation of releases

- Low corrosion rate of glass

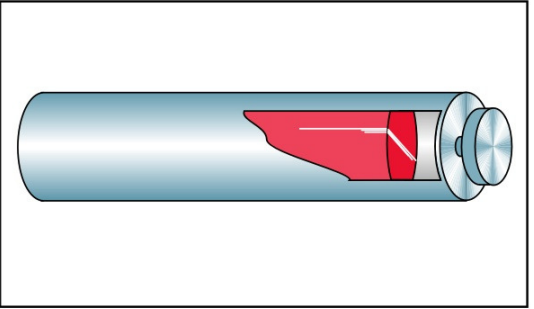

Steel canister

- Confinement

Prevents inflow of water and release of radionuclides from waste for several thousand years

- Attenuation of releases

- Corrosion products act as reducing agent

(giving low radionuclide solubilities)

Corrosion products take up radionuclides

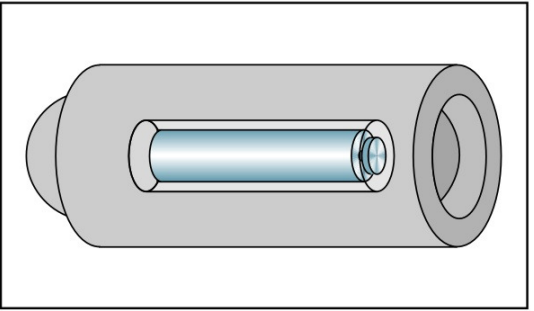

Bentonite backfil

- Confinement

- Long resaturation time

- Plasticity (self-sealing following physica disturbance)

- Attenuation of releases

- Low solute transport rates (diffusion)

- Retardation of radionuclide transport

(sorption)

- Low radionuclide solubility in pore water

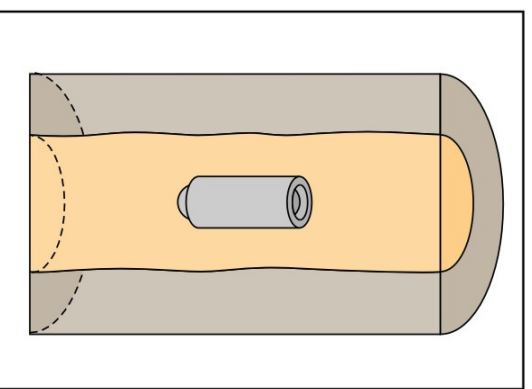

Geological barriers

\section{Host rock}

- Confinement

- Absence of water-conducting features

Mechanical stability

- Attenuation of releases

- Low groundwater flux

Retardation of radionuclide transport (sorption and colloid filtration)

Geosphere

- Confinement

- Physical protection of the engineered barriers

(e.g. from glacial erosion)

- Attenuation of releases

- Retardation of radionuclide transport (sorption)

- Dispersion

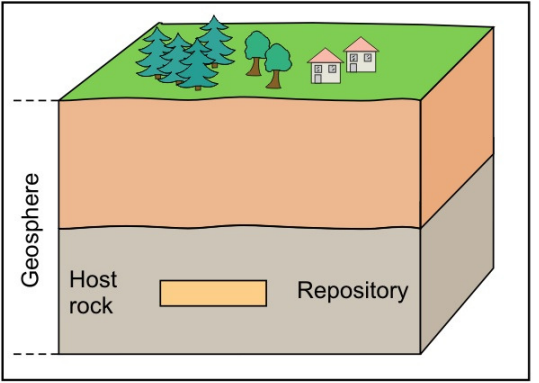

Figure 6 